\title{
Assessment of genetic diversity in Fusarium wilt tolerant and susceptible oil palm (Elaeis guineensis Jacq) progenies in Nigeria using inter- simple sequence repeat (ISSR) molecular markers
}

Nnamdi Ifechukwude Chidi ( $\sim$ swissswissy@yahoo.co.uk)

Nigerian Institute for Oil Palm Research https://orcid.org/0000-0002-3146-2385

Adedotun Adeyinka Adekunle

University of Lagos

Temitope Oluwaseun Samuel

University of Lagos

Emmanuel Ifechukwude Eziashi

Nigerian Institute for Oil Palm Research

David Okeh Igwe

Ebonyi State University

\section{Research article}

Keywords: Elaeis guineensis, ISSR markers, Tolerance, Susceptible, Genetic diversity

Posted Date: August 28th, 2019

DOI: https://doi.org/10.21203/rs.2.12913/v1

License: (c) (i) This work is licensed under a Creative Commons Attribution 4.0 International License.

Read Full License 


\section{Abstract}

Background Improving oil palm in Nigeria for food security and subsequent export requires a better understanding of the genetic diversity among oil palm progenies tolerant and susceptible to Fusarium wilt disease. In view of the limitations of the orthodox method used in screening this disease, and the advantages of molecular markers, fourteen (14) Inter-simple sequence repeat (ISSR) DNA markers were applied to evaluate the genetic diversity, population structure and cluster resolutions of alleles responsible for tolerance of 560 Elaeis guineensis Jacq palms representing 8 different progenies distributed across NigeriaResults The amplification product revealed a moderately high level of genetic diversity with a total of 46 alleles identified, resulting in an average of 4.9091 alleles per locus detected between the oil palm progenies. Polymorphic information content (PIC) values varied between 0.37060.7861 , with a mean value of 0.6829 . The genetic diversity values ranged from $0.4063-0.8125$ with a mean of 0.7216 , while the major allele frequency ranged from $0.2500-0.7500$ with a mean value of 0.3750 . Shannon's information index (I), Nei's gene diversity $(\mathrm{H})$, and the effective number of alleles $(\mathrm{Ne})$ had values of $0.6931,0.5000$, and 2.000 , respectively. The genetic diversity was highest in progeny 3023 , and lowest in progeny 4189 . Mean values of the total gene diversity $(\mathrm{Ht})$, gene diversity within the population (Hs) of the progenies, coefficient of gene differentiation among the progenies (Gst) and level of gene flow $(\mathrm{Nm})$ were $0.4899,0.3520,0.2815$ and 1.2764 , respectively. The dendrogram clustered the progenies into six major clusters, while Principal Component Analysis (PCA) grouped the progenies into five clusters. PCA further identified the coordinate positions of tolerant and susceptible alleles of oil palm progeniesConclusion This study confirmed the identification of the coordinate positions of tolerant alleles in the gene loci, which could be exploited by breeders to developing tolerant oil palm seedlings.

\section{Background}

Oil palm (Elaeis guineensis Jacq) is a crop that lasts for more than two growing seasons. It is allogamous and of African origin. Oil palm is the highest oil-yielding crop in the world. Nigeria, the most populous nation in Africa, is the fourth largest world palm oil producing country and number one in Africa. In the humid tropical areas of Africa, there are not less than 43 countries where the crop is cultivated presently (Sheil et al.,, 2009; FAO, 2015). A high percentage, greater than $30 \%$ of vegetable oil, is generated from this crop, which makes it stand out in fat supply to the world (USDA, 2015). The plant, apart from being the producer of palm oil which humans take in as a diet, is also essential in body insulation and energy to people domiciled in a lot of developing countries (Goh et al.,, 2016). The problem of maintaining production and development of oil palm establishment has been raising issues not only to the local sphere of plant science but also in the fields of economics (Rival et al.,, 2016).

The crop is vulnerable to many diseases, and the most devastating of them all in Africa is the Fusarium wilt disease whose causative agent is Fusarium oxysporum f.sp elaeidis (Paterson et al.,, 2013; Noumouha et al.,, 2014). The production of oil palm in Africa is cut drastically by the effects of this disease (Ntsomboh et al.,, 2015). The devastating effects of this disease are as high as 70\%, and some factors which include areas where the condition had occurred do favour the sudden emergence of the 
disease (Rival, 2017). Fusarium as genera includes many species which are capable of causing the physical manifestation of a disease. The causative agent is soil borne; however, it is still possible for the pathogen transmitted by rain and wind (Leslie and Summerell, 2006). There as some saprophytic species of Fusarium which are soil borne and have the ability to live and utilize the dead organic matter of the oil palm trunk, while some species live as endophytes inside the palm and do not cause disease to the palm.

The genetic diversity that exists among plant cultivars makes it easier for breeders to manipulate and enhance traits which are desirable to farmers and suitable to breeders (pest and disease resistance). In carrying out the genetic assessment, the genetic diversity that is possessed by plant progenies may not be at par with the physical observation of traits or essential characters, but has many benefits over the morphological assessment (Govindaraj et al.,, 2015). It is evident to note that varieties that possess high genetic diversity identified by molecular markers could be used and taken as a standard in the breeding process (Van Zonneveld et al.,, 2012; llves et al.,, 2013; Vinceti et al.,, 2013).

Molecular markers which entail Amplified fragment length polymorphism (AFLP), Simple sequence repeat (SSR), and Randomly amplified polymorphic DNA (RAPD) have been applied in the investigation of genetic variability and genetic affiliation between different plant species (Igwe et al.,, 2017). The (ISSR) marker system is a PCR based system that makes use of a single amplification primer which is made up of a set of repeated DNA motifs that targets the microsatellite regions (Salis et al., 2017). Inter-simple sequence repeat markers target multiple genomic loci and amplify DNA segments that occur in between two microsatellite regions that face each other in terms of orientation.

The deployment of classical breeding techniques geared at improving beneficial traits to farmers like tolerance to pathogenic organisms requires the assessment of many different progenies. However, to assess progenies for tolerance phenotypically, it requires lots of finance and above all can be affected by environmental factors. The use of classical breeding in classifying individual varieties into various clusters adopts morphological features but has limitations because they do not reveal real genetic relationships and other shortcomings. The advantage of ISSR markers of not requiring sequence data for primer design and the allelic richness it possesses was essential for adopting in this study. The identification of the genetic relationships, population structure that exists among Fusarium wilt tolerant and susceptible oil palm progenies, and the determination of the coordinate positions of tolerant alleles possessed by oil palm progenies which could be exploited by breeders in developing tolerant oil palm plant lines.

\section{Methods}

\section{Sample Collection and DNA Extraction}

A total of 560 palms representing eight progenies were sampled from the fields of oil palms containing susceptible and tolerant oil palm progenies. The progenies were selected based on their use for the basis of screening purposes (Table

1) (Figure 1). For each progeny, 70 palms were sampled based on the availability of the samples. Approximately 100 
mg of fresh young unopened leaves were harvested from each palm. The leaves were subsequently cleaned and maintained at $-80^{0} \mathrm{C}$. The total genomic DNA extraction was carried out using the CTAB method with little modifications.

\section{Polymerase Chain Reaction and Agarose Gel Electrophoresis}

Polymerase chain reaction (PCR) amplification was accomplished by mixing together $1.50 \mu$ of $50 \mathrm{mM} \mathrm{MgCl} 2$ (BIOLINE Massachusetts, USA), $2.00 \mu \mathrm{l}$ of $2.50 \mathrm{mM}$ dNTPs (BIOLINE, Massachusetts, USA), $0.20 \mu \mathrm{l} 500 \mathrm{U}$ Taq DNA polymerase (BIOLINE, Massachusetts, USA), $1.0 \mu \mathrm{l}$ of $10 \mu \mathrm{M}$ each of ISSR primer pair, $15.05 \mu \mathrm{l}$ of $500 \mathrm{ml}$ diethyl pyrocarbonate (DEPC)-treated water (INVITROGEN, Carlsbad, CA, USA) and $2.0 \mu \mathrm{L} 100 \mathrm{ng}$ DNA, $2.5 \mu \mathrm{l}$ of 10× Taq Buffer (BIOLINE, Massachusetts, USA) to make up a volume of $24.25 \mu \mathrm{L}$. The list of ISSR markers, their sequences, and annealing temperatures are presented in Table 2. The PCR cycling profile employed for the reaction entailed an initial step at $94{ }^{\circ} \mathrm{C}$ for $5 \mathrm{~min}$., succeeded by 35 cycles of $94{ }^{\circ} \mathrm{C}$ for $30 \mathrm{~s}, 72{ }^{\circ} \mathrm{C}$ for $1 \mathrm{~min}$., and a 10 min last extension at $72{ }^{\circ} \mathrm{C}$. For the PCR reaction, eight (8) $\mu \mathrm{l}$ of the PCR products were electrophoresed in a $1.5 \%$ agarose gel comprising $0.5 \mathrm{mg} / \mathrm{ml}$ ethidium bromide and photographed on Transilluminator UV light (Fotodyne Incorporated, Analyst Express, USA).

\section{Data Analyses}

The data matrix of ISSR profiles obtained from fragments of each amplicon was scored as 1 (presence of alleles) and 0 (absence of alleles). The data generated from the scoring of the ISSR amplicons were employed for phylogenetic reconstruction using Unweighted Pair Group Mean with Arithmetic (UPGMA) and dissimilarity index in Jaccardøs option (Ojuederie et al., 2013). The analysis was carried out using NTSYSpc software version 2.02. Furthermore, genetic diversity, allele frequency, and the polymorphic information content (PIC) were analysed using PowerMarker Version 3.25. Genetic diversity and population structure analyses of the oil palm progenies were analyzed using POPGENE software version 1.32. Also, total gene diversity (Ht), gene diversity within the population (Hs), the level of gene flow $(\mathrm{Nm})$, and the coefficient of gene differentiation (Gst) were calculated with POPGENE software version 1.32 (Yeh et al., 1999).

\section{Table 1: Background derivation of susceptible and tolerant oil palm progenies screened}




\begin{tabular}{|c|c|c|c|c|c|}
\hline S/NO & FIELD(S) & PALM NUMBER & PEDIGREE & STATUS & PROGENY \\
\hline \multicolumn{6}{|c|}{ CODE } \\
\hline 1 & $25(4.17 \times 4.17)$ & 120 & Aba Dura & Susceptible & 1 \\
\hline 2 & $25(3.361 \times 1.53)$ & 2211 & Calabar x Dura & Susceptible & 8 \\
\hline 3 & $25(32.2824 \times 1.2209)$ & 3023 & Angola Dura & Susceptible & 4 \\
\hline 4 & $25(5.1225 x G 145)$ & 2478 & Serdang Ave Deli Dura & Susceptible & 15 \\
\hline 5 & $25(26 / 0932 x G 144)$ & 3456 & Malaya Deli Dura & Susceptible & 3 \\
\hline 6 & $54(31.5703 \mathrm{dx} 31.5703 \mathrm{~d})$ & 1621 & Ecuador Dura & Tolerant & 8 \\
\hline 7 & $54(25.3337 d \times 25.3337 d)$ & 1723 & Ecuador Dura & Tolerant & 10 \\
\hline 8 & $25(6.594 \times 5.1450)$ & 4189 & Calabar Tenera & Susceptible & 11 \\
\hline
\end{tabular}

\section{Figure 1: The GIS map site of susceptible and tolerant oil palm sample collection in Nigeria}

Table 2: ISSR primers used for genetic diversity and population structure analysis of oil palm 


\begin{tabular}{lllll}
\hline 1 & ISSR 836 & AGAGAGAGAGAGAGAGTA & $57^{0} \mathrm{C}$ & 44.4 \\
\hline 2 & ISSR 858 & TGTGTGTGTGTGTGTGGT & $52^{0} \mathrm{C}$ & 50 \\
\hline 3 & ISSR 890 & GTAGTGTGTGTGTGTGT & $54^{0} \mathrm{C}$ & 41 \\
\hline 4 & ISSR 868 & GAAGAAGAAGAAGAAGAA & $50^{\circ} \mathrm{C}$ & 33 \\
\hline 5 & ISSR 826 & ACACACACACACACACC & $52^{\circ} \mathrm{C}$ & 53 \\
\hline 6 & HB-12 & CACCACCACGC & $48.5^{\circ} \mathrm{C}$ & 47 \\
\hline 7 & ISSR 888 & CAGCACACACACACACA & $58.5^{\circ} \mathrm{C}$ & 52.17 \\
\hline 8 & ISSR 818 & CACACACACACACACAG & $48^{\circ} \mathrm{C}$ & 52.94 \\
\hline 9 & ISSR 889 & ATTACACACACACACAC & $52^{\circ} \mathrm{C}$ & 41.2 \\
\hline 10 & ISSR 827 & ACACACACACACACACG & $53^{\circ} \mathrm{C}$ & 53 \\
\hline
\end{tabular}

\section{Results}

Genetic diversity interpretations revealed by Inter-simple sequence repeat molecular markers

To assess the degree of genetic diversity of 560 palms representing eight (8) different progenies of oil palm, fourteen (14) ISSR molecular markers were verified. Ten (10) out of the 14 markers produced scorable bands and used in the diversity investigation (Plate 1). A dendrogram using Unweighted Pair Group Mean Arithmetic (UPGMA) and dissimilarity index clustered the progenies into six significant clusters based on their genetic similarities and divergence (Figure 2). Cluster 1 grouped two susceptible progenies (3023 and 2211) at a booth trap of 10\% between 
them. Apart from they are both susceptible progenies, they were grouped based on shared ancestry/ parentage of the progenies. Taking a close examination at the first cluster, progeny 3023 is an Angola Dura, while progeny 2211 is a cross between Calabar and Aba Dura. However, progeny 3023, which is an Angola Dura, has parentage of (Ufuma and Angola) which is (P8). Ufuma itself has a link with P1 (Ufuma and Aba). Progeny 2211 has a parent of Calabar and Aba which is P3. Cluster II consists of just one susceptible progeny (120) with a booth trap of $11 \%$. Cluster III contained only one tolerant progeny (1621) with a booth trap of 12\%. Cluster IV equally included one susceptible progeny (2478) with a booth trap of $13 \%$. Cluster V contained one susceptible (3456) together with progeny (1723) which is a tolerant progeny with a booth trap of $14 \%$ but clustered together due to a common origin. Taking an insight into this cluster, progeny 1723 is an Ecuador Dura, while progeny 3456 is a Malay Deli Dura. Progeny 1723 has parentage of Ecuador Deli (BB4). The clustering was a result of the common origin, Deli, which is an ethnic group in Indonesia. Cluster VI contained just one susceptible progeny (4189) with a booth trap of $16 \%$ all from the Nigerian (Figure 2 and Table 3 ).

Plate 1: PCR amplification profile of oil palm DNA fragments using ISSR markers (ISSR 890, ISSR 836 and ISSR 827). M=100bp step DNA ladder, 1-6(progeny 120, susceptible), (progeny 2211, susceptible), (progeny 3023, susceptible), progeny 2478, susceptible), progeny 3456, susceptible) and progeny 1621, tolerant) 7-8(progeny 1723 , tolerant) and (progeny 4189, susceptible.

Figure 2: Dendrogram of oil palm progenies amplified with ISSR molecular markers

Principal component analysis grouped the oil palm progenies into five clusters (Figure 3), which is different from the clustering of the dendrogram as a result of the region of coverage of the markers. Cluster 1 clustered progeny 2478 (Serdand Ave Deli Dura). Cluster 2 clustered progenies 120 (Aba Dura); progeny 3023(Angola Dura) and progeny 2211 (Calabar and Aba Dura) together. Looking at this cluster, they all share the same parent P1 (Ufuma and Aba). Cluster 3 clustered progeny 3456 alone. Cluster 4 clustered progeny 1723 (Ecuador Dura) and progeny 1621 (Ecuador Dura) due to familiar parents, Ecuador Deli (BB4). Cluster V clustered progeny 4189 (Calabar Tenera). Each group was a representative of a unique allele possessed by the oil palm progenies.

Figure 3: Principal component analysis of oil palm progenies based on Inter-simple sequence repeat markers

\section{Genetic structure and progeny differentiation}

The ten (10) ISSR primers amplified a total of 46 alleles. The amplified alleles from each marker ranged from 3-6, with a mean of 4.9091 (Table 4). Polymorphic information content (PIC) values ranged from 0.3706-0.7861 with a mean value of 0.6829. The ISSR markers ISSR836, ISSR858, ISSR890, ISSR868, ISSR826, HB-12, ISSR888, ISSR818, and ISSR889 were found to be polymorphic, while ISSR827 was monomorphic with the least PIC value. The genetic diversity values ranged from 0.4063-0.8125 with a mean of 0.7216, while the major allele frequency ranged from 0.2500- 0.7500 with a mean value of 0.3750. Allelic scores count and frequencies obtained from Elaeis guineensis (oil palm) progenies using Inter-simple sequence repeat (ISSR) markers (Additional file 1: Table S1). The genetic diversity in progenies 3023 and 2478 which are both susceptible progenies were identified to be the highest with effective number of alleles (Ne), Nei's gene diversity $(\mathrm{H})$ and Shannon's information index (I) values of 2.000, 0.5000, 0.6931 
respectively (Table 5), while the genetic diversity in progeny 4189 (Susceptible) and 3456 (Susceptible) using ISSR markers was found to be the lowest with $\mathrm{Ne}, \mathrm{H}$, and I value of $1.9007,0.4739,0.6668$. The genetic diversity values of these progenies were ranked as progenies 3023>2478> 1621>1723>120>2211>3456> 4189 from high to low based on polymorphism at the ISSR loci. The Ne, $\mathrm{H}$ and I values ranged from 1.9007-2.000, 0.4739-0.5000, 0.66680.6931 .

From the ISSR markers, the mean values and standard deviation of $\mathrm{Ne}, \mathrm{H}$ and I from the whole progenies were $1.9614 \pm 0.0427,0.4899 \pm 0.0112,0.6830 \pm 0.0113$ (Table 5). The closeness in the genetic diversity values recorded could be as a result of inbreeding, and the limited change in allelic frequency. From the genetic differentiation using the ISSR markers, the mean values of the total gene diversity $(\mathrm{Ht})$, gene diversity within the population of the progenies (Hs), coefficient of gene differentiation or gene diversity among the population (Gst) and level of gene flow $(\mathrm{Nm})$ were $0.4899,0.3520,0.2815$ and 1.2764 respectively (Table 6). The Ht values ranged from 0.4739-0.5000; Hs values varied from 0.2612-0.4163; Gst from 0.1673-0.4488 and Nm values from 0.6142-2.4878. The diversity among the oil palm progenies was as a result of high gene flow in the system which led to the high diversity found in progeny 3023, and the low gene flow leading to low diversity in progeny 4189.

The coordinates generated through the principal coordinate analysis showed the coordinates and positions of unique alleles generated on the factorial axis of the gene loci of the oil palm progenies (Table 7). It showed the pointers on the principal component scale, which determined the positions and status grouping of the oil palm progenies. Based on the coordinates, it pointed out the distinctions between the tolerant and susceptible progenies separated from each other on the factorial axis. These coordinates indicated the divergence and drift among the breeding populations. Based on these coordinates, it showed progeny 4189 , which is a susceptible progeny grouped in the same principal component axis where we had two tolerant progenies of 1621 and 1723; this could mean that progeny 4189 could be tagged an illegitimate palm. 


\section{Discussion}

The inability of farmers to access healthy seedlings has resulted in farmers looking elsewhere and collecting seedlings from doubtful local and foreign sources. Some have had to import seedlings to meet their planting targets, where such imported seedlings which failed in the field due to susceptibility to Fusarium wilt disease may plunge investors into financial crisis. The above raises the issue of unrestricted importation of oil palm seedlings. It has also drawn attention for the need to thoroughly screen the oil palm seedlings to curb the menace of Fusarium wilt disease. However, the revelation of molecular markers in screening has made the work easier in identifying the coordinates and positions of alleles, genetic sequences responsible for Fusarium wilt and tolerance in oil palm progenies. Therefore, genetic diversity study using informative markers is essential in genetic improvement and also in the identification of unique alleles. In this study, ISSR markers were used to assess the level of genetic diversity, relationships among the different progenies of oil palm from various growing fields and cluster resolutions of tolerant and susceptible alleles.

The majority of the primers used produced bands that are scorable and used in the diversity analysis; this, however, is in agreement with the study of Saptadi et al. (2017) which stated that RAPD and ISSR markers evaluated produced scorable bands for further analysis. Similar studies of Igwe et al. (2017) revealed that four (4) out of the ten primers produced scorable bands used in the diversity investigation. Further reports to support this study are the studies of Srivastav et al. (2013) and Zehdi et al. (2004), which revealed polymorphic scorable bands generated by ISSR molecular markers.

The ISSR markers produced a dendrogram which clustered the oil palm progenies into six significant clusters based on their genetic similarities and divergence which they inherited from their parental cross. So progenies found in the same group or cluster share some similar inherited traits, while those found in different clusters are genetically dissimilar; this is in line with the studies of Igwe et al. (2017); Igwe and Afiukwa (2017) and Cheng et al. (2018) which stated that the cluster analysis grouped their population into more than two groups. However, apart from the genetic similarities or divergence, some of the oil palm progenies like progeny 3023 and progeny 2211 which are both susceptible were grouped in the same cluster because they share the same ancestry/ parentage; this is in accordance with the report of Okoye (2016) which stated the dendrogram classification of accessions into various clades with parents' grouped separately into a clade using SSR markers.

In some of the clusters, there was a clustering of a susceptible (3456) progeny with a tolerant progeny (1723). In this case, the grouping was not due to genetic similarities, but because they share a common origin. Taking a look at their relationship implies that progeny 1723 is an Ecuador Dura, while progeny 3456 is a Malay Deli Dura. Progeny 1723 has a parent of an Ecuador Deli (BB4) which led to the clustering; this, however, agrees with the report of Okoye (2016) which stated that some oil palm progenies were grouped with a parent-progeny because they share a common origin.

The Principal Component Analysis (PCA) amplified by ISSR molecular markers, resolved the progenies into five clusters, which was different from the dendrogram, which grouped the oil palm progenies into six 
distinct clusters. The principal component analysis clustered some of the progenies 120 , which is an Aba Dura; progeny 3023 (Angola Dura), and progeny 2211 (Calabar and Aba Dura) because they share a familiar parent P1, which is a combination of Calabar and Aba Dura. This study disagrees with the study of Okoye (2016), which stated that based on the principal coordinate plot, some parents differentiated themselves from other parents. Furthermore, the clustering between a tolerant progeny 1621 (Ecuador Dura) and another tolerant progeny 1723 (Ecuador Dura) by PCA in this study was as a result of each progeny possessing a representative of a unique allele which they inherited from a familiar parent BB4 (Ecuador Deli). The survey of Okoye (2016) agrees with this report in stating that some progenies were clustered together due to their link with a familiar male parent.

The majority of the ISSR markers revealed high values for a total number of alleles, mean numbers of alleles, PIC, genetic diversity and the total number of polymorphic loci. It showed that the ISSR primers amplified a total of 46 alleles whereby each allele amplified ranged from 3-6, with a mean of 4.9091 . The study is comparable to the findings of Igwe and Afiukwa (2017), which detected high values of alleles by SCoT markers with a mean value of 16.200. The report of Singh et al. (2014) further supported this study by revealing high allele number of 83 identified from accessions of Vigna species when analyzed with ISSR molecular markers.

The low mean number of alleles of 4.9091 as compared to the studies of Igwe et al. (2017) was as a result of a limited number of descendants for their inter-crosses and number of ISSR markers used for the diversity study. However, it is backed with the study of Singh et al. (2008) which reported a lower number of alleles per locus $(2.2$ - 3.2) in oil palm when analyzed with fewer numbers of SSR molecular markers.

The frequency of the alleles for all the ISSR markers used for this diversity study as well as that of the different progenies of oil palm varied. In as much as the progenies varied in terms of some being susceptible and some tolerant; among the susceptible progenies still revealed varied allelic frequencies which could be attributed to the fact that when populations remain small for any extended period, sampling effects may become cumulative, and gene frequencies can undergo relatively large fluctuations between generations, resulting in low-frequency alleles. The variations in the number of alleles and PIC values observed in this study (ISSR: 46 alleles; $0.3706-0.7861$ PIC) could be as a result of the different progenies with so many genotypes coming into play because of the difference in the genetic constitution. The markers revealed a mean gene diversity of 0.7216 for ISSR markers. These values indicate the high allelic richness and genetic diversity among the different progenies of the oil palm, and also demonstrated the higher efficiency of the markers in differentiating the progenies.

More than $80 \%$ of the oil palm progenies shared a common major allele frequency of 0.3750 at any given locus. However, the presence of the same number of observed alleles of 2.000 found in both the susceptible and tolerant progenies could be that they may not be too genetically dissimilar since most of them either share the same ancestry, parents or origin. In determining the best ISSR markers used for detecting DNA polymorphism, the discriminating power of each ISSR markers was scrutinized by calculating their polymorphic information content (PIC). A PIC value of greater than 0.7 is considered to 
be highly revealing, while a value of 0.44 is adjudged to be mildly revealing. The result of this study revealed a high average PIC value of (mean $=0.6829)$ in all tested ISSR markers. It further revealed that apart from ISSR827 with the lowest PIC (0.3706), ISSR836 had the highest PIC (0.7861) which would be the best in identifying the genetic diversity in different progenies of oil palm. This marker was followed by ISSR858 (0.7544), ISSR890 (0.7456), ISSR868 (0.7119), ISSR826 (0.7119), HB-12(0.6675), ISSR888 (0.6675), ISSR818 (0.6299), and ISSR889 (0.6050). A similar report from Gwag et al. (2010) and Ouoba et al. (2017) revealed that the values of PIC recorded for DAMD and SCoT markers were higher than 0.345 and 0.298 when ISSR markers were used for the analysis on Vigna radiata and Vigna subterranea accessions. The PIC values identified in this study revealed that ten of the ISSR markers were able to identify the genetic diversity between the different oil palm progenies, which is in agreement with the study of Okoye et al. (2016) which reported that the PIC values generated by SSR markers were helpful in the assessment of the diversity inequity between genotypes.

Nei is the measurement for effective allele numbers deduced from each population. It is the inverse value of the homozygosity. The higher the value of $\mathrm{Ne}$, the more the individual is heterozygous (Nabila et al.,, 2014). Nei's genetic diversity, numbers of effective alleles as well as Shannon's information index are very crucial in the study of genetic diversity in plant species (Freeland et al.,, 2011). In this study, the Nei's genetic diversity $(\mathrm{Ne})$, effective number of alleles $(\mathrm{H})$ and Shannon's information index $(\mathrm{I})$ were highest in progenies 3023(32.2824x1.2209) and 2478(5.1225xG145) with values of 2.000, 0.5000, 0.6931 which are both susceptible progenies, while progeny $4189(6.594 \times 5.1450)$ (susceptible) was found to be the lowest with $\mathrm{Ne}, \mathrm{H}$, and I value of $1.9007,0.4739,0.6668$ using ISSR molecular markers. This report is in line with what Igwe and Afiukwa (2017) reported which revealed values of $\mathrm{Ne}, \mathrm{H}$ and I ranging from $1.183-1.593,0.196-0.324$, and 0.328-0.464 when investigated with DAMD markers.

The observed allele per locus ( $\mathrm{Na})$ of 2.00 in this study was found to be the same in all progenies. However, the effective number of alleles $(\mathrm{Ne})$ was different for all the different progenies of oil palm. The effective number of the allele was topmost in progenies $3023(32.2824 \times 1.2209)$ and $2478(5.1225 \times G 145)$ with values of 2.00, while the least values of 1.9007 were found in progenies $3456(26 / 0932 \times G 144)$ and $4189(6.594 \times 5.1450)$. These values were lower than that reported by Nabila et al. (2014) of a value of 2.92 in the FFB population of oil palm. The low values of an effective number of alleles in this study are as a result of the genetic material used. The materials used were Dura materials that have crossed with pollen from selected Dura or Pisifera seedlings, which confer traits of similar genetic materials as a result of having a joint genetic base.

In assessing the obtained values of total gene diversities $(\mathrm{Ht})$, gene diversity within population $(\mathrm{Hs})$, coefficient of gene differentiation (Gst) and estimated gene flow $(\mathrm{Nm})$ detected in the progenies with ISSR polymorphic markers, progenies $3023(32.2824 \times 1.2209)$ and $2478(5.1225 \times G 145)$ was revealed to have the highest values of $\mathrm{Ht}=0.5000)$ which is in agreement with the study of Igwe et al. (2017) which stated highest total diversity (Hs) in Vigna unguiculata from Ebonyi state. The levels of total gene diversity in all the progenies in this study were higher than that of what Hamrick, 1989 reported using SSR markers. The gene diversity within the population was highest in progenies 3023(32.2824x1.2209) and 
1621 (31.5703dx31.5703d) with values of $\mathrm{Hs}=0.4163$ and 0.3837 respectively, which is also in line with the study of Igwe et al. (2017) using ISSR markers.

Indirect population genetics statistics estimate gene flow as the number of individual genes migrating from one population to the other and per generation $(\mathrm{Nm})$, and its influence is significant in the distribution of genetic materials. Gene flow in the analysis was highest in progenies $3023(32.2824 \times 1.2209)$ and $3456(26 / 0932 \times G 144)$ with values of 2.4878 and 1.9087 , respectively. It could be as a result of progenies $3023(32.2824 \times 1.2209)$, and 3456(26/0932xG144) being in the same location and of proximity in the field containing susceptible plant lines caused by seed and pollen movement, thus leading to low levels of genetic divergence seen among some of the progenies. Czarnecki et al. (2008) stated high gene flow values of 9.47 and 6.16 in their report.

The genetic differentiation (Gst) is classified as low when its value is $<0.05$, medium when its value is $0.05<$ Gst $<0.15$ and high when Gst $>0.15$. So, the Gst coefficient of the oil palm progenies was very high. The obtained value of the coefficient of gene differentiation (Gst $=0.2815$ ) indicated that only about $8 \%$ of the total genetic divergence was because of isolation by geographic distance and natural selection, while $92 \%$ was due to the mating system and gene flow. However, there is an exception to the main cause of coefficient of gene differentiation in the sense that progenies $3456(26 / 0932 \times G 144)$ (susceptible) and $4189(6.594 \times 5.1450)$ (susceptible) grouped by dendrogram and progenies 1723 (tolerant) (25.3337dx25.3337d) and 1621) (31.5703dx31.5703d) (tolerant) grouped by principal component analysis were of different locations. The susceptible and tolerant progenies were grouped, which means that they share a common parentage, ancestry or origin, but separated by distance, so there should be other factors that led to this. This high genetic differentiation within the progenies of oil palm could be as a result of the transfer of genetic materials from parental cross to corresponding descendants, which is in agreement with the study of Twyford et al. (2013) stating that high genetic differentiation could be linked to outcrossing pollination process and exchange of genetic materials.

The coordinates generated through the principal coordinate analysis revealed the coordinates and positions of unique alleles generated on the factorial axis of the gene loci of the oil palm progenies. The coordinates are pointers on the principal component scale which determines the positions and status grouping of the oil palm progenies. Based on the coordinates, it pointed out the variations that exist between the tolerant and susceptible progenies separated from each other on the principal component scale. These coordinates showed the heterozygosity and drift among the breeding populations. Based on these coordinates, it showed progeny 4189 and 1723, regarded as susceptible and tolerant progenies clustered on the other side of the principal component scale as compared to the different susceptible progenies clustered on the other axis. However, this could be attributed to contamination, or to the fact that progeny 4189 is an illegitimate palm caused by several reasons, like, wrong labelling, using wrong pollens for pollination, and poor blotting of the male inflorescence to prevent self-pollination. The report of Okoye (2016) supported the study by stating that the occurrence of unexpected fruit forms is an indication of illegitimacy or contamination. Further reports from Okoye (2016) said that illegitimate 
hybrids are individual samples whose genotype or allelic configuration does not conform to the allelic shape of their putative parents.

\section{Conclusions}

The result of this study proved that the ISSR markers employed had reliable discriminating power on the different progenies of oil palm as indicated by the values of the genetic diversity as well as the number of alleles per primer, PIC values, per cent polymorphism, and other parameters. The discovery of coordinates of alleles by PCA possessed by oil palm progenies which are responsible for tolerance or susceptibility could be applied by plant breeders in developing tolerant free oil palm progenies for oil palm farmers to increase food production.

\section{Abbreviations}

AFLP: Amplified fragment length polymorphism; Gs: Coefficient of differentiation; H: Nei's genetic diversity; Hs: Gene diversity within population; Ht: Total genetic diversity among population; I: Shannon's information index; ISSR: Inter-simple sequence repeat; Ne: Effective number of alleles; Nm: Level of gene flow; NPL: Number of polymorphic loci; PCR: Polymerase chain reaction; PIC: Polymorphic information content; PPL: Percentage polymorphic loci; RAPD: Random amplified polymorphic DNA; SSR: Simple sequence repeat; UPGMA: Unweighted pair group mean with arithmetic; St. dev: Standard deviation

\section{Declarations}

\section{Acknowledgements}

The authors are grateful to the Nigerian Institute for Oil Palm Research (NIFOR), the University of Lagos and the Biotechnology Research and Development Center (BRDC), Ebonyi State University for providing the facilities required for this research work. I also want to acknowledge the International Institute of Tropical Agriculture (IITA), Ibadan. Mr Jonah and Mrs Ogbeiye Charity from Plant Pathology Division, NIFOR are exceptionally recognized for helping out in the sample collection.

\section{Funding}

\section{No funding was received to conduct this study.}

\section{Availability of data and materials}

\section{Every data produced during this study are included presently in this published article.}




\title{
Authors' contributions
}

NIC and AAA envisaged and designed the research; NIC carried out the study; Data evaluation was executed by NIC, AAA, TOS, EIE and DOI. AAA, TOS and EIE reviewed the manuscript. All authors have read and given consent to the final manuscript.

\section{Ethics approval and consent to participate}

Permission was granted by the management of the Nigerian Institute for Oil Palm Research before entering the various plantations to collect samples.

\section{Consent for publication}

\author{
Not applicable.
}

Competing interests

\section{The authors declare that they have no competing interests.}

\section{Publisher's Note}

Springer Nature remains neutral with regard to jurisdictional claims in published maps and institutional affiliations.

\section{Author details}

${ }^{1}$ Plant Pathology Division, Nigerian Institute for Oil Palm Research (NIFOR), Edo State, Nigeria. ${ }^{2}$ Botany Department, University of Lagos, Akoka, Yaba, Lagos State, Nigeria. ${ }^{3}$ Botany Department, University of Lagos, Akoka, Yaba, Lagos State, Nigeria. ${ }^{4}$ Plant Pathology Division, Nigerian Institute for Oil Palm Research (NIFOR), Edo State, Nigeria. ${ }^{5}$ Department of Biotechnology, Ebonyi State University, Abakaliki, Ebonyi State P.M.B 053, Nigeria

\section{References}


1. Cheng J, Jiang D, Cheng H, Zhou X, Fang Y, Zhangi X, Xiao X, Deng X, Li L. Determination of Camellia oleifera Abel. Germplasm Resources of Genetic Diversity in China using ISSR Markers. Not. Bot. Horti. Agrobot. Cluj-Na. (2018); 46(2): 501-8. 2. Czarnecki DM, Nageswara RM, Norcini JG, Gmitter FG, Deng Z. Genetic diversity and differentiation among natural, production and introduced populations of the narrowly endemic species Coreopsis leaven worthii (Asteraceae). J. Am. Soc. Hortic. Sci. (2008); 133:234-41. 3. El-Rabbat S, El-Maghraby O, El-Debaiky S, Haider A. Isolation and Molecular Identification of Fusarium Species from Some Cereal Grains and Their Products in Egypt. Int. J. Innov. Sci. Eng. Technol. ISSN (2018); 5(2): 2348-7968. 4. Elshibli S. Korpelainen H. Biodiversity in date palm: molecular markers as indicators. In: Date Palm Biotechnology. Jain S M. Al-Khayri JM. Johnson DV. (Eds.). Springer, Dordrecht, Netherlands. (2011); p. 371-406. 5. Food and Agriculture Organization of the United States Nations (FAO). The State of Food Insecurity in the World 2015. Meeting the 2015 international hunger targets: taking stock of uneven progress. Rome. (2015); pp62 6. Freeland J, Kirk H. Petersen S. Molecular Ecology. 2nd edition, Chichester, UK: John Wiley and Sons. (2011); pp165 7. Goh CS, Wicke B, Faaij A, Bird DN, Schwaiger $H$, Junginger M. Linking carbon stock change from land-use change to consumption of agricultural products: Alternative perspectives. J. Environ. Manage. (2016); 182: 542-56 8. Govindaraj M, Vetriventhan M, Srinivasan M. Importance of Genetic Diversity Assessment in Crop Plants and Its Recent Advances: An Overview of Its Analytical Perspectives. Genet Res Int. (2015); http://dx.doi.org/10.1155/2015/431487 9. Gwag J, Dixit A, Park YJ, Ma KH, Kwon SJ, Cho GT, Lee GA, Lee SY, Kang HK, Lee SH. Assessment of genetic diversity and population structure in mungbean. Genes Genom. (2010); 32: 299-308. 10. Hamrick JL. Isozymes and the analysis of genetic structure in plant population. In: Isozymes in Plant Biology. Soltis DE. Soltis PS. (Eds.). Dioscorides Press, Portland, (1989); p. 87-105. 11. Igwe DO. Afiukwa CA. Competency Assessment of Directed Amplified Minisatellite DNA and Start Codon Targeted Markers for Genetic Diversity Study in Accessions of Vigna subterranea (L.) Verdcourt. J. Crop Sci. Biotechnol. (2017); 20(4): 263-78 12. Igwe DO, Afiukwa CA, Ubi B E, Ogbu K I, Ojuederie O B, Ude GN. Assessment of genetic diversity in Vigna unguiculata L. (Walp) accessions using inter-simple sequence repeat (ISSR) and start codon targeted (SCoT) polymorphic markers. BMC Genet. (2017); 18: 98-111. 13. Ilves A, Lanno K, Sammul M, Tali K. Genetic variability, population size and reproduction potential in Ligularia sibirica (L.) populations in Estonia. Conserv. Genet. (2013); 14:661-9. 14. Leslie JF, Summerell BA. The Fusarium Laboratory Manual (First edition). Blackwell Publishing, Asia State Avenue, U.S.A. (2006); pp369 15. Nabila MS, Sobir, Toruan-Mathius N. Genetic Diversity of DxP Population Yield Component in Oil Palm's Paternal Half-Sib Family Based on Microsatellite Markers. Energy procedia, (2014); 47: 196-203. 16. Noumouha E N, Ghislain, Allou D, Adon B, Konan J N, Diabate S, Konan K E, Simon-Pierre A, Nguetta. Assessment of Nigerian wild oil palm (Elaeis guineensis Jacq.) populations in crosses with Deli testers. J. Plant Breed. Genet. (2014); 2(2): 77-86. 17. Ntsomboh N G, Madi G, Nyaka N A, Nsimi M A, Epoh N T, Kato S N, Lum A F, Ngando E G F. Vascular Wilt Disease Tolerance Status of Some Oil Palm (Elaeis guineensis Jacq.) Progenies in Relation to Local Strains of Fusarium oxysporum f. sp. elaeidis in Cameroon. Int. J. Curr. Res. Biosci. Plant Biol. (2015); 2(8): 111-22. 18. Ojuederie OB, Igwe DO, Okuofu SI, Faloy B. Assessment of Genetic Diversity in some Moringa oleifera Lam. Landraces from Western Nigeria using RAPD Markers. The African Journal of Plant Science and Biotechnology (2013); 7(1): 15-20. 19. Okoye NM, Uguru MI, Bakoumé C, Singh R, Okwuagwu CO. 
Assessment of Genetic Diversity of NIFOR Oil Palm Main Breeding Parent Genotypes Using Microsatellite Markers. Am. J. Plant Sci. (2016); 7: 218-37. 20. Okoye M N. Molecular Characterization of some NIFOR and Elite Oil Palm Breeding Populations using Microsatellite Markers. PhD thesis, University of Nigeria, Nigeria. (2016); pp165. 21. Ouoba A, Ouedraogo M, Sawadogo M, Nadembega S. Aperçu de la culture du voandzou (Vigna subterranea (L.) Verdcourt) au Burkina Faso: enjeux et perspectives d'amélioration de sa productivité. Int. J. Bio. Chem. Sci. (2016); 10(2): 652-65. 22. Paterson RRM, Sariah M, Lima N. How will climate change affect oil palm fungal diseases? Crop Prot. (2013); 46: 113-20. 23. Rival A. Breeding the oil palm (Elaeis guineensis Jacq.) for climate change. OCL. (2017); 24(1): 107 24. Rival A, Montet D, Pioch D. Certification, labelling and traceability of palm oil: can we build confidence from trustworthy standards? OCL. (2016); 23(6): 609. 25. Salis RK, Bruder A, Piggott JJ, Summerfield TC, Matthaei CD. High throughput amplicon sequencing and stream benthic bacteria: identifying the best taxonomic level for multiple-stressor research. Sci. Rep. (2017); 7: 44657-69. 26. Saptadi D, Hartati RS, Setiawan A, Sudarsono, Heliyanto B. Genetic Diversity of Indonesian Physic Nut (J. curcas) Based on Molecular Markers. Agriv. J. Agric. Sci. (2017); 39(2): 160-71. 27. Sheil D, Casson A, Meijaard E, van Nordwijk M, Gaskell J, Sunderland-Groves J, Wertz K, Kanninen M. The impacts and opportunities of oil palm in Southeast Asia: What do we know and what do we need to know? Occasional paper, No. 51. CIFOR, Bogor, Indonesia. (2009); pp 80. 28. Singh R, Noorhariza MZ, Ting NC, Rozana R, Tan SG, Low LET, Ithnin $\mathrm{M}$, Cheah SC. Exploiting an oil palm EST the development of gene-derived and their exploitation for assessment of genetic diversity. Biologia. (2008); 63:1-9. 29. Singh A, Dikshit HK, Jain N, Singh D, Yadav RN. Efficiency of SSR, ISSR and RAPD markers in molecular characterization of mungbean and other Vigna species. J. Biotechnol. (2014); 13: 81-8. 30. Srivashtav C V, Kapadia M K, Mahatma S K, Jha S, Jha, Ahmad T. Genetic diversity analysis of date palm (Phoenix dactylifera L.) in the Kutch region of India using RAPD and ISSR markers. Emir. J. Food Agr. (2013); 25(11): 907-15. 31. Twyford AD, Kidner CK, Harrison N, Ennos RA. Population history and seed dispersal in widespread Central American Begonia species (Begoniaceae) inferred from plastome-derived microsatellite markers. Bot. J. Linn. Soc. (2013); 171: 260-276 32. United States Department of Agriculture (USDA). Dietary Guidelines for Americans. 8th Edition. (2015); pp144. 33. Van Zonneveld M, Scheldeman X, Escribano P, Viruel MA, Van Damme P, Garcia W. Mapping genetic diversity of cherimoya (Annona cherimola mill.) and application of spatial analysis of conservation and use of plant genetic. PLoS One. (2012); 7(1):e29845. 34. Vinceti B, Loo J, Gaisberger H, Van Zonneveld MJ, Schueler S, Konrad H. Conservation priorities for Prunus africana defined with the aid of spatial analysis of genetic data and climatic variables. PLoS One. (2013); 8(3):e59987 35. Yeh F C, Boyle R, Yang R C, Ye Z, Mao J X, Yeh D. POPGENE version 1.32. Computer program and documentation distributed by the author. (1999). Website: http://www.ualberta.ca/ fyeh/popgene.html. 36. Zehdi S, Trifi M, Ould MSA, Rhouma A, Marrakchi M. Molecular characterization of Tunisian date palm germplasm using ISSR markers. J. Genet. Genomics. (2004); 56: 77-83.

\section{Tables}

Due to technical limitations, tables 3-7 are only available as a download in the supplemental files section 
Figures

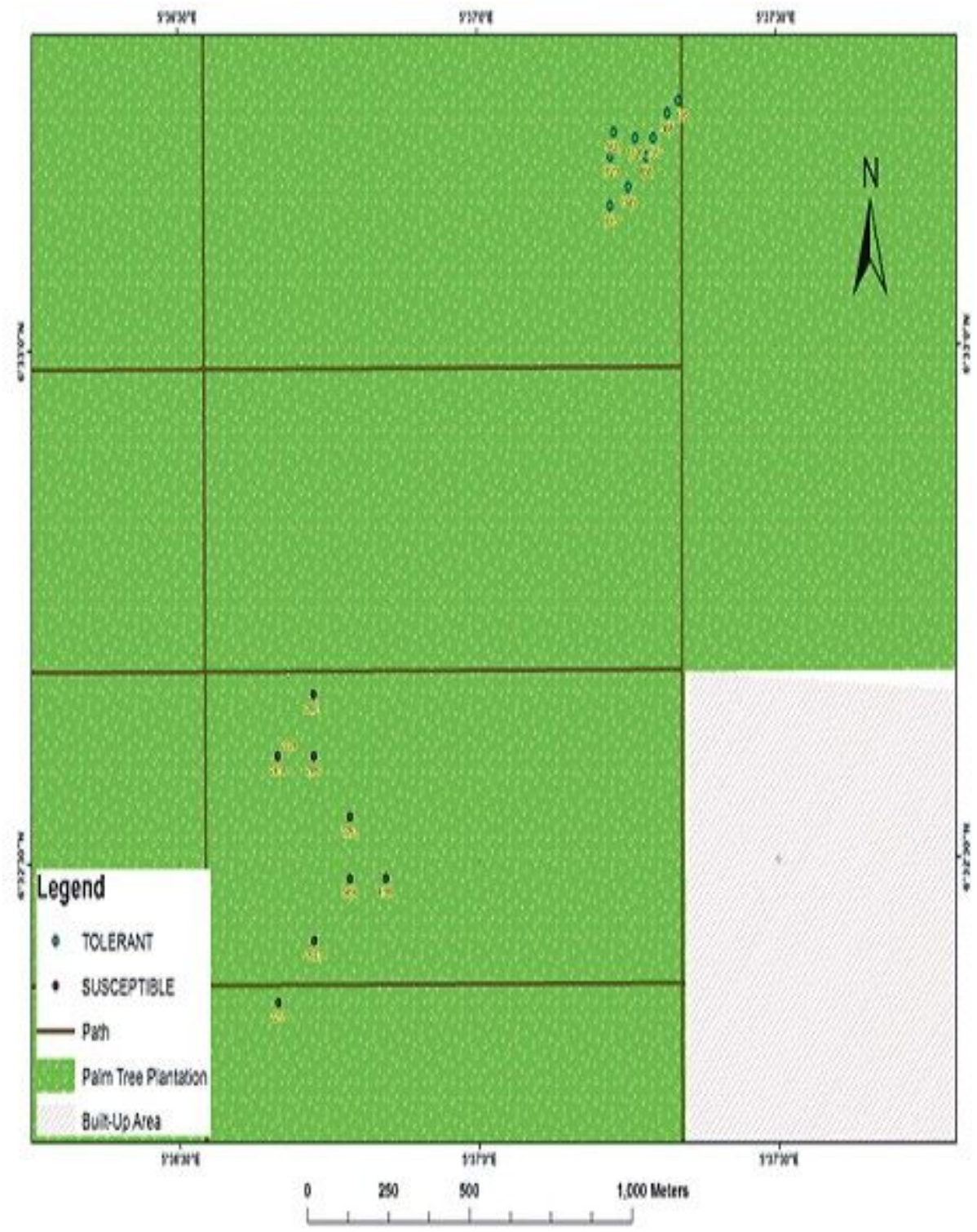

Figure 1

The GIS map site of susceptible and tolerant oil palm sample collection in Nigeria 


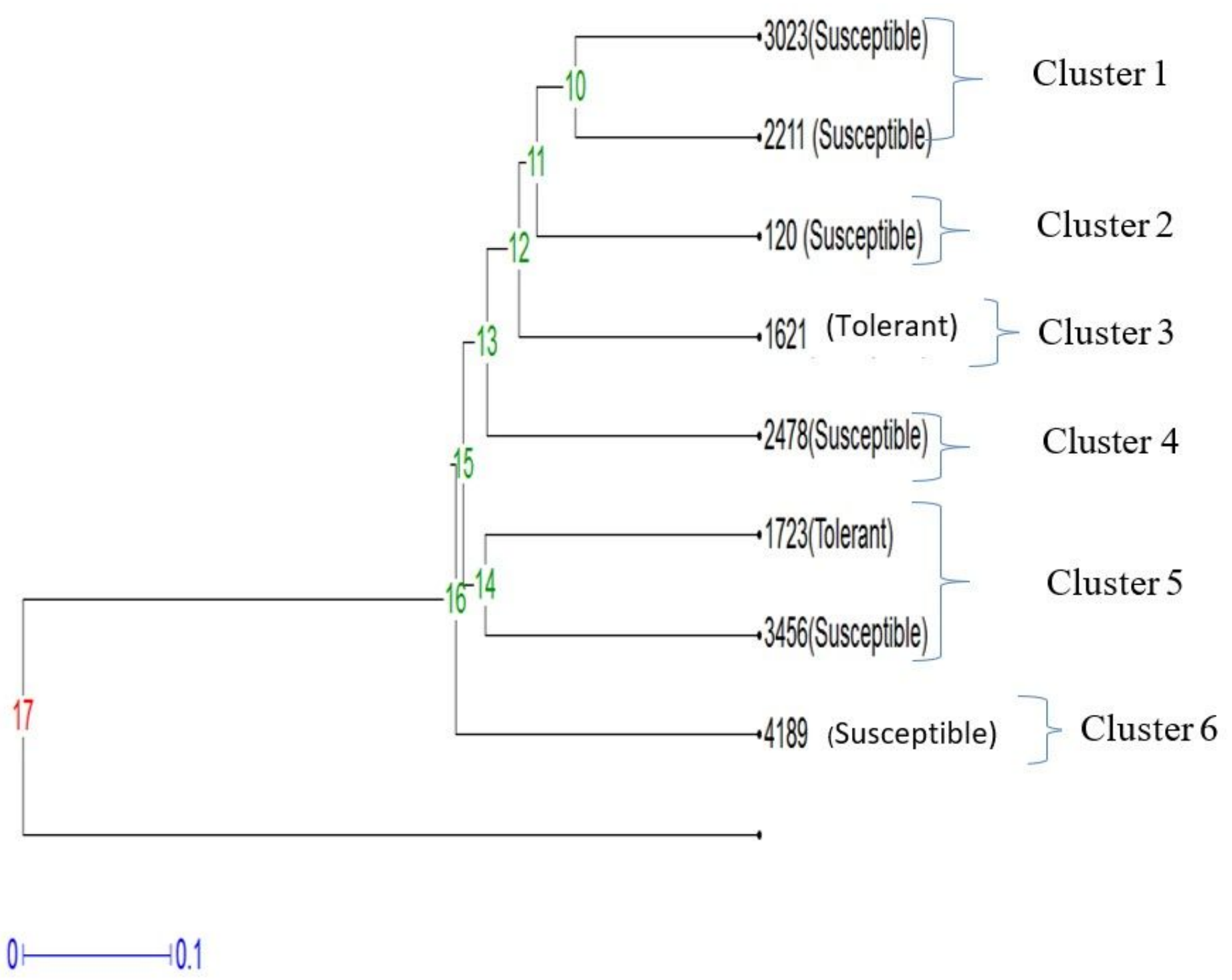

Figure 2

Dendrogram of oil palm progenies amplified with ISSR molecular markers 


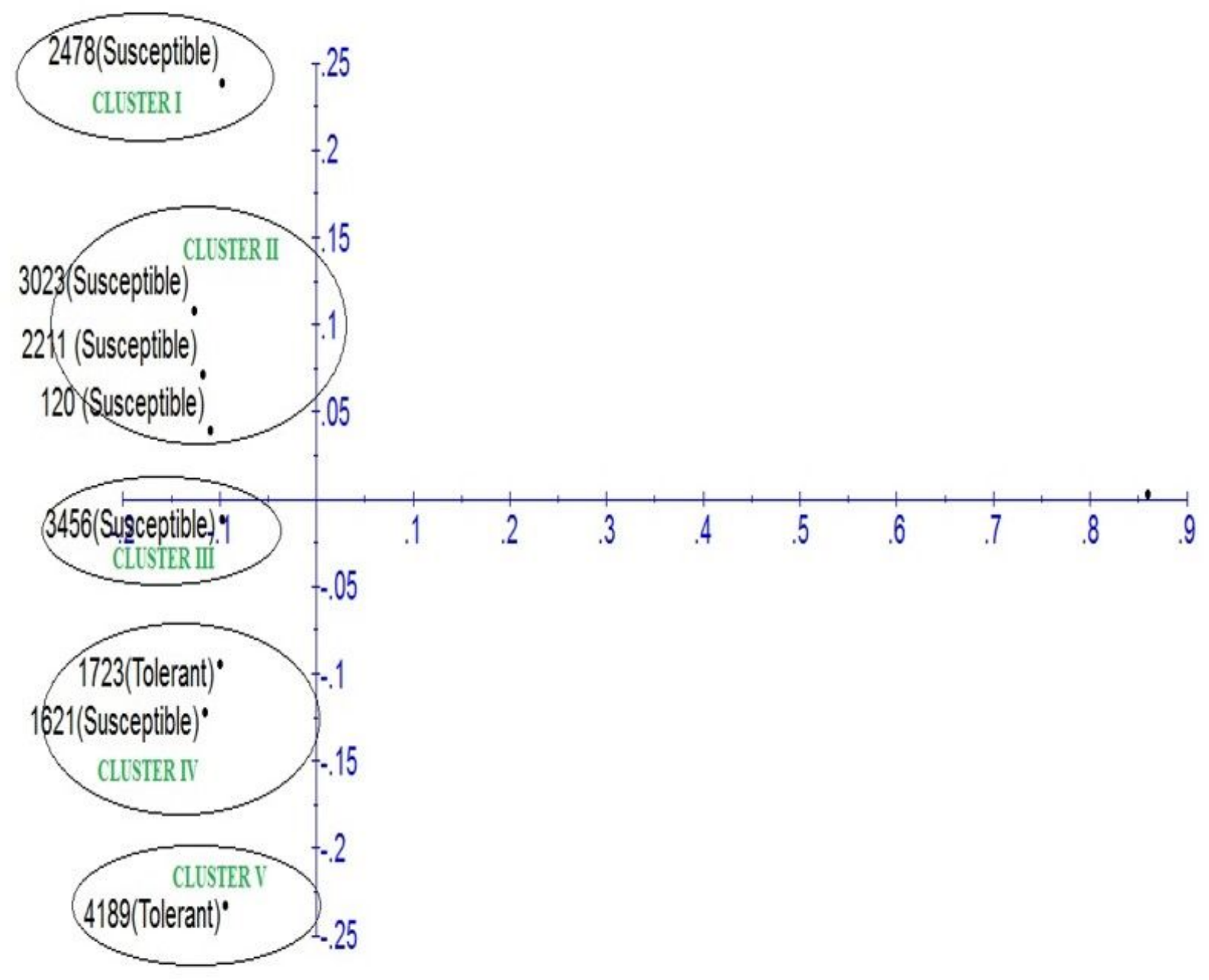

Figure 3

Principal component analysis of oil palm progenies based on Inter-simple sequence repeat markers

\section{Supplementary Files}

This is a list of supplementary files associated with this preprint. Click to download.

- Additionalfile1.docx.pdf

- Plate1.jpg

- Tables37.docx 